\title{
Pathologic Length
}

National Cancer Institute

\section{Source}

National Cancer Institute. Pathologic Length. NCI Thesaurus. Code C158773.

The longest perpendicular diameter of a tumor from the pathology examination of a specimen. 